Отримано: 12 січня 2020 року

Прорецензовано: 23 січня 2020 року

Прийнято до друку: 29 січня 2020 року

e-mail: valerymykhaylenko@i.ua

DOI: $10.25264 / 2519-2558-2020-9(77)-160-163$
Mykhaylenko V. V. Ordering of modifiers in the multi-noun phrase of SL and TL. Науковi записки Наиіонального університету «Острозька академія»: серія «Філологія». Острог: Вид-во НаУОА, 2020. Вип. 9(77). С. 160-163.

\author{
Valery V. Mykhaylenko, \\ Doctor of Philology, Professor \\ King Danylo University, Ivano-Frankivsk (Ukraine)
}

\title{
ORDERING OF MODIFIERS IN THE MULTI-NOUN PHRASE OF SL AND TL
}

In this paper there is an overview of ordering in English multi-noun phrases (MNP) or poly-adjectival nominal phrases (PNP) and the model of semantic ordering is revealed:[Det] + MODIFIERS (+ size [Adj] + shape [Adj] + age[Adj] - colour [Adj + nationality [Adj] + HEADWORD [Noun]. The transformation patterns of rendering English MNPs into Ukrainian ones are recognized and we developed a relevant analysis of MNPS. This project concerns the ordering among modifiers in poly-adjectival nominal phrases (PNP) coined by Bache (1978) to refer to any noun phrase which contains more than one modifier(see also Georgi, 2010). We considered the concept of ordering the constituents in the multi-NP (MNP) in the process of translating from English into Ukrainian. Sproat and Shih (1988) provide one of the most comprehensive cross-linguistic analyses of adjective ordering restrictions, and suggest that the semantic-based ordering theories proposed for English are largely universal across languages. This rearrangement of ordering is triggered by the Ukrainian synthetic grammar structure which permits free word order in the phrase and a sentence, and a change of the communicative focus by the translator. A modifier is defined as words or phrases which premodify the head word of the phrase and can postmodify it as well. From 150 pages of the novel "Angels ad Demons" by Dan Brown and its Ukrainian translation by Aнжела Кам'янець only 35 multi-noun phrases have been retrieved as an object of our study which we have classified into 4 groups according to the type of transformation (equivalent, permutation, addition, and omission). There is one of the main arguments for the rearrangment motivation of noun headwords and modifiers is the opposition of the author's and translator's intentional meaning. In addition we put forward a hypothesis - the both transformations are motivated by the semanticsof modifiers. The Semantic Model of ordering adjectives in the English multi-noun phrase must be verified in various discourse registers to define common and distinctivefeatures of this phenomenon.

Key words: multi-noun phrase, modifier, ordering, translation, semantic model.

\author{
Михайленко Валерій Васильович, \\ доктор філології, професор \\ Університет Короля Данила, Івано-Франківськ (Украӥна)
}

\section{ПОСЛІДОВНІСТЬ МОФІКАТОРІВ У МУЛЬТІ-ІМЕННИКОВІЙ ФРАЗІ В МОВІ ДЖЕРЕЛА ТА МОВІ ПЕРЕКЛАДУ}

У данй роботі проаналізовано публікачії з послідовності модифікаторів в англійському мультікомпонентному (або полікомпонентному) іменниковому словосполученні (MNP) / (PNP) i вирізнено модель семантичної послідовності модифікаторів: [Dеt] + MODIFIERS (+ size [Adj] + shape) [Adj] + вік [Adj] - колір [Adj]+ національність [Adj]) + HEADWORD [Iменник]. Визначено трансформачійні матричі МNP/ PNP при перекладі украӥнською мовою. Зі 150 сторінок роману «Ангели і демони» Дена Брауна та його українського перекладу Анжелою Кам'янець лише 35 багатокомпонентних іменникових словосполучень було зареєстровано у мові оригіналу як об 'єкт нашого дослідження, щчо утворюють 4 групи за типом трансформацій, серед яких чільне місие посідає пермутаиія.

Ключові слова: багатокомпонентне іменникове словосполучення, модифікатор, послідовність, переклад, сементична модель.

Defining the problem and argumentation of the topicality. In this paper we consider the concept of ordering the constituents in the multi-NP (MNP) in the process of translating from English into Ukrainian. Sproat and Shih provide one of the most comprehensive cross-linguistic analyses of adjective ordering restrictions, and put forward the thesis that the semantic-based order theories proposed for English are largely universal across languages [17, p. 591].

This rearrangement of ordering is triggered by the Ukrainian synthetic grammar structure which permits free word order in the phrase and a sentence, and a change of the communicative focus by the translator. There is another term for the MNP - a polyadjectival nominal phrase (PNP)' coined by Bache (1978) to refer to a noun phrase with two or more adjectival modifiers [see also 8, p. 1-2]. He defines a modifier as 'words or phrases which premodify the head word of the phrase and can postmodify it as well [1, p. 11-12; 12, p. 371-372].

Analysis of recent research and publications There have been countless attempts to reveal the ordering restrictions in English PNPs with many theorists focussing on the semantic content of adjectives [3; 16]. From a semantic viewpoint noun phrases discribe objects and the work. Bache is a particularly important scholar for this project, as he examined PNPs focussing not only on semanticbased ordering, but also on the function of each adjective [1, p. 26; see also 6, p.14]. He suggests that all modification in English noun phrases could be grouped into three modificational zones featuring adjectives which specify (Mod-I), characterize (Mod-II), and classify (Mod-III), andthey are identified by Bache based on their semantic properties and syntactic behaviour. The most common property of adjectives which has been studied on a cross-linguistic level is that of the ordering of adjectives and noun. Greenberg notes that "certain languages tend consistently to put modifying or limiting elements before those modified or limited, while others just as consistently to do the opposite [9, p.75], i.e different languages may have different syntactic structure in accordance with their typological feature. Dryer adds that 'in some languages, both orders of adjectives and noun occur. The conclusion is that one of the two orders is dominant. The author also stresses that in some languages, either order is possible, with no dominant order [5, p. 798]. Many languages are said to possess one clear order of adjectives and noun though they also have a limited subclass of adjectives which appear in the postposition of the headword (e.g.: govenor general, secretary general, etc.). But this is true of 
Ukrainian in which adjectives are typically prenominal but with some adjectives which often appear postnominally. Bache claims that 'judging from common usage, there seems to be a limit of about six or seven adjectives, though most PNPs contain only two or three adjectives [1, p. 11-14]. Quirk et al (1985) stress that 'although there is, theoretically, no grammatical upper limit tothe number of premodifiers, it is unusual to find more than three or four'. Litosseliti believes that issues of design, collection and analysis of data cam involve various methods [7, p. 1). This paper involves the collection and the analysis of a variety of different forms of PNP in the SL and TL. Much of the work done on the adjective class concerns the variability of the lexical category in terms of morphology and syntax. Perhaps, the most commonly investigated area is that of the order of adjective and noun (see13, p. 13]. The order among modifiers in PNP s is of particular interest to linguists - pre-posed adjectives and post-posed adjectives in MNP [Quirk, 1985:1286,1293; see also 1fl.). Bache (1978) analyzes such phrases as having a reversible or non-reversible order, with the former subcategorised into distinctive and non-distinctive orders. Non-reversible orders appear in noun phrases in which only one ordering of them difiers is grammatically possible [9, p.46]. Reversible sequences can have adjectives appearing in various orders, without affecting the grammaticality of the phrase.

The purpose and the objectives of the article. We propose a contrastive analysis of the ordering of modifiers of the English MNP in the novel "Angels and Demons by Dn Brown and its Ukrainian translation bу Анжела Кам'янець rendering according to which we wiil differentiate between regularities and irregularities of ordering modifiers within the phrase.The scope of the present investigation is the translation of English noun phrases: prepositional and postpositional into Ukranian. And we want to uderstand whether the Ukrainian translator follows the MT MNP syntactic structure or change the ordering. It will help us to reveal the typology of odering as a model for the tranlators from English into Ukrainian.

The outline of the main research material. The NP arrangement and rearrangement have been researched intensively in linguistics, psycho-linguistics, philosophy, and computational linguistics for a long time. The semantic interpretation [13, p. 77-78; see also18] of rearrangement proves to be very difficult for a number of reasons: (1) sometimes the meaning changes with the head (make/produce, theme), (2) with the modifier (make/produce, possession). (3) There can be a number of possible semantic relations between the given pair of word constituents, for example, a location and a part-whole relation; (4) interpretation of rearrangement may be highly context-dependent in the TL [cf 4]. The following NP level constructions are considered in this paper:

(1) compound nominals consisting of two consecutive nouns; (2) adjective noun constructions where the adjectival modifier is derived from a noun -- a make/produce relation; (3) genitives -- a part-whole relation;

(4) adjective phrases (cf. Quirk, 1985) in which the modifier noun is expressed by a prepositional phrase which functions as an adjective - a LOCATION relation, cf. the classifications provided by Quirk et al (1985) and Semmelmeyer (1992). Dixon proposes seven semantic subclasses of dimension;physical property; colour; human propensity; value; speed speed [3, p. 15-6; cf 10:111-2; 11, p. 2-3).

We understand that the detective genre prescribes the author to use 'simplified' syntax of phrase, therefore, for example, very few three - constituent-noun phrases are registered in our corpus to say nothing of four or five- component-noun $\mathrm{n}$ phrases. The translator tries to keep to the Ukrainian syntactical rules and s/he rearranges some prepositive adjectives to the postpositive, but there is a domain feature of reordering.

From 150 pages only English 35 multi-noun phrases have been retrieved as an object of our study which we have classified into 4 groups among which Group B is the most frequent:

A. No changes in the Ukrainian ordering $(=6)$

1. Det + Modifier (second degree) + Modifier $+\mathbf{N} \rightarrow$ Modifier + Modifier $+\mathbf{N}:$ an arrestingly deep voice $\rightarrow$ заворожливий низький голос. Here the translator retains the NP structure and finds proper TL equivalents for the SL modifiers.

2. $\mathbf{N}+$ Prep (of) $+\mathbf{N}<$ Adj) + Prep(in) +Ipos + Modifier + Modifier $+\mathbf{N} \rightarrow$ Modifier $+\mathbf{N}+$ Prep(в) +Modifier + Modifier $+\mathbf{N}:$ wisps of gray in his thick brown hair $\rightarrow$ срібні пасма в густому темному волосci. The SL syntactic structre of a two-component NP with a modifier expressed by a prepositional three-component NP is retained in the TL. Though there are some lexical shifts: the noun пасма has a negative component 'пучок волосся, зокрема патлатого, but the adjective срібні added by the translator tincture the noun пасма with a positive shade, in the same phrase brown hair loses there is a specific colour and it is generalized as темне.Warren suggests that adjectives appearing closer to the head carry a stronger 'classificatory strength'(Warren, 1984:283), while others refersto the word class or morphological derivation of an adjective as determining its position within a string.

3. Modifier + Modifier $+\mathbf{N} \rightarrow$ Modifier + Modifier $+\mathbf{N}$ : Uncontrollable, relentless guilt $\rightarrow$ Страшна, жахлива провина. То underline the feeling of horror it was substituted by neutral incontrollable by an emotionally marked cmрашнаand relentless 'showing or promising no abatement of severity, intensity, strength, or pace' bу жахлива. The translator tries to introduce into the Ukrainian text colloquialisms.

B. Change in the Ukrainian ordering $(=21)$

1. Prep(on) +Ipos +Modifier + Modifier (Genetive) $\rightarrow$ Prep + Modifier $+\mathbf{N}+$ Modifier + N: on his brass Maharishi's chest $\rightarrow$ на мідну скриню східного гуру.

English adjectives appear almost exclusively before the noun (with the exception of a few French calques and marked with stylistic usages). The structure of the English phrase is transformed into the PrepNP' на мідну скриню' and a postpositional modifier східного гуру the adjectiveсхідногоbroadens the meaning Maharishi'from 'Indian' to 'oriental.' Besides, the chest is made of wood decorated and strengthend with brass, but not made of brass midi. The modifier Maharishi's 'a Hindu teacher of mystical knowledge substituted by the noun guru'a Hindu teacher of mystical knowledge,' they may be synonymous but the component of 'a great Hindu sage or spiritual leader(Webster)' is lost.The loss of the possessive pronoun his and the possessive case of Maharishi 's' ownership of the chest is not clear. To my mind, the postpositional modifier could be translated аs'який належав колись.'

2. Ipos + Modifier + Modifier $(\mathbf{N})+\mathbf{N} \rightarrow$ does not correspond to the Ukrainian structure, which changes the focus from attire to the character :his usual classroom attire $\rightarrow$ як зазвичай одягавсяв університеті. The Ukrainian structure does not correspond to the English one, which changesthe focus from attire to the character, see attire 'clothes, esp. of a particular type,' i.e. the translator changed the pathos speech Noun: $\rightarrow$ Verb. 
3. Det + Modifier + Modifier $+\mathbf{N}+$ Prep (of) -+ Modifier $\rightarrow$ Modifier + Modifier $+\mathbf{N}+$ Prep $(\mathbf{y})+\mathbf{N}+$ Modifier $(\mathbf{N}):$ the strong,carefree smile of a collegiate athlete $\rightarrow$ щіру безтурботну посмішку у спортсмена аматора. The structure is retained though the relationshp in the prepositional phrase differs; the rendering of strong (smile) is not an equivalent for Ukrainian mipo, which is apparently closer to відкрита, широка; спортсмен аматор is generalisation of the specific університетський спортсмен.

4. Prep (by) +Def +modifier (Npos) + Modifier + Modifier $+\mathbf{N} \rightarrow$ Modifier $+\mathbf{N}:$

by the building's striking transparent design $\rightarrow$ незвичайний дизайн. Due to the change of the informational focus of the sentence: Actor (Langdon) to Object (Building design) there is also a transformation of the English Active voice into the Ukrainian Passive voice. There is also a generalisation of building'a usually roofed and walled structure built for permanent use (as for a dwelling); cf Ukrainian cпоруда “рукотворне утворення (об’єкт), споруджене будівельними засобами, призначене для виконання господарських або інших функцій”:

5. Det + Modifier $+\mathbf{N}+$ Modifier $($ Of Phrase $\leftarrow$ Det + Npos + Modifier superlative + Conj + Modifier (superlative) + Modifier + Modifier $+\mathbf{N} \rightarrow($ Prepositional phrase Modifier + Modifier $+\mathbf{N}+($ Postpositional phrase): The long-lost symbol of the world's oldest and most powerful satanic symbol $\rightarrow$ давно втрачений символ найстарішого й наймогутнішого в світі культуСатани. There is a rearrangement in the postpositional phrase: Modifier $+\mathrm{N}$ (satanic symbol) $\rightarrow \mathrm{N}+$ Modifier (культу Cатани) and the noun symbol "object having cultural significance and the capacity to excite or objectify a response" (Webster) is substituted in Ukrainian by an object having cultural significance and the capacity to excite or objective response, cf Ukrainian «поклоніння кому-, чомунебудь, шанування когось, чогось" which is more negative in meaning.

6. Det + Modifier + Modier $\rightarrow$ Modifier $+\mathbf{N}=$ Prep + Modifier + Modifier $+\mathbf{N}$ :

A smooth cement tunnel,-- широченний тунель з голими бетонними стінами. Brown and Yule note that authors can choose to foreground or 'thematize' the most important element of an utterance by placing it furthest left in the phrase [2, 135]. The translator permutated one constituentin the prepositional modifier to the postposition and expanded the both: (1) иироченний and (2) голими, the adjective smooth 'a continuous even surface' is substituted for the adjective голими.

7. Modifier (N's) + Modifier + Modifier $+\mathbf{N} \rightarrow$ Modifier + Modifier $+\mathbf{N}+$ Modifier: CERN's standard keypad security $\rightarrow$ стандартний кодовий замок ЦЕРНу. There is a regular differentiation of the English Noun Phrase with the headword in the postposition into the Ukrainian prepositional and postpositional modifiers and the translator as usually moves the focus from the front into the final position.

8. Prep (to) +Det +Modifier (N's) + Modifier + Modifier $(\mathbf{N})+\mathbf{N}:$ to an intricate electronic device $\rightarrow$ на складний електронний пристрій. The first modifier is moved to the postposition of the headword as for semantics the translator found proper Ukrainian correspondences.

9. Prep (to) + Modifier + Modifier $(\mathbf{N})+\mathbf{N} \rightarrow \mathbf{S}$ : extreme energy densities $\rightarrow$ Щільність цієї енергії надзвичайно висока. Тhе translator transformed the English NP into a Ukrainian simple sentence.

10. Modifier + Modofier $+\mathbf{N}+$ Modifier $\rightarrow$ Modifier + N + Prep (3) +

Modifier + N: Antimatter reverse polarity vacuum $\rightarrow$ вакуумний контейнер з протилежною полярністю. There is a regular permutation of the foci causing a syntactic transformation, besides, the translator added the noun container to stress that antimatter is secured in it.

11. Modifier + Modifier $(\mathbf{N})+\mathbf{N} \rightarrow$ Modifier $+\mathbf{N}+$ Prep (для) + Modifier $(\mathbf{N}):$ ultimate terrorist weapon. $\rightarrow$ ідеальна зброя для терористів.

There is moving of a modifier terrorist to the postposition of the head word. The adjective ultimate 'being the best or most extreme example of its kind (Webster)' is substituted by - ідеальна (досконалий, відмінний, чудовий), in thiscase the positive component of ідеальна does not fit the context.

C. Omission of the constituents (=4)

1. Det + Modifier $+\mathbf{N} \rightarrow$ omitted: a fledgling government $\rightarrow X$. The English phrase is ommited by the translator and the modifier many of whose leaders were Masons the translator did not point out that those statesmen were masons, so the historical information is lost.

2. Det +Modifier + Modifier+ Modifier $+\mathbf{N} \rightarrow$ Modifier + Noun: A Harris tweed suit jacket $\rightarrow$ твідовий піджак. Тhe transformation of SL structure resulted in the simplification of the phras meaning. Harris tweed $\mathrm{s}$ a'thick woollen cloth for making coats, jacketswoven by hand on the islands of Harris and Lewis in the Outer Hebrides (Webster). Besides, suit jacket in classic menswear it is part of a suit.The translator narrowed the meaning of a Harris tweed suit jacket by simplifying it into more usual for the Ukrainian reader. We must admit that the cultural component of the phrase is also lost.

D. Addition of modifiers $(=3)$

1. Det + Modifier + Modifier $+\mathbf{N} \rightarrow$ Modifier (superl.) $+\mathbf{N}++$ Prep (3) +Modifier $+\mathbf{N}$ : a wide cannonlike barrel $\rightarrow$ широченна труба з оптичним прицілом. The translator used the superlative adjective to intensfy the huge dimension of the barrel. And there is a prepositional noun phrase is added to specify the type of the barrel.

2. Det $+\mathbf{N}+$ Prep (Of) $+\mathbf{N}+$ Modifier + Modifier $\rightarrow$ Modifier + Modifier $+\mathbf{N}:$

a tangle of electronics dangling below. $\rightarrow$ безліч електронних причандалів. The tangle 'a mass of confusedly interlaced or intertwisted threads, strands' is substituted by безліч and a colloquial причандали is added which does not fit the professional discourse.

Conclusions and prospects for futher research. The principles governing the order of demonstrative, numeral, adjective, and noun are based on semantic categories, not syntactic ones. The Semantic Model of ordering adjectives in the English multi- noun phrase is Det -size - shape - age - colour - nationality - headword that must be verified in various discourse registers to define common and distinctive features of the phenomenon

\section{References:}

1. Bache C. The order of pre-modifying adjectives in present-day English. Odense: Odense UP, 1978. 99 p.

2. Brown G., Yule G. Discourse analysis. New York: CUP, 1989. 302 p.

3. Dixon R. M. W. Where have all the adjectives gone? Berlin: Walter de Gruyter, 2010. 270 p. 
4. Downing P. On the creation and use of English compound. Language. 1977. Vol. 53. P. 810-42.

5. Dryer M. S. On the order of demonstrative, numeral, adjective, and noun. Language. 2018. Vol. 94(4). P.798-833.

6. Ferris D. Connor. The Meaning of syntax: A study in the adjectives of English. London: Longman, 1993. 235 p.

7. Flanagan P. J. A Cross-linguistic investigation of the order of attributive adjectives. Ph.D.Thesis. Edge Hill University, 2014. 352 p.

8. Georgi D., Muller G. Noun-phrase structure by reprojection. Syntax. 2010. Vol. 13(1). P. 1-36.

9. Greenberg J. H. Some universals of grammar with particular reference to the order of meaningful elements / Ed. J. Greenberg. Universals of human language. Cambridge, Mass: MIT Press, 1963. P. 73-113.

10. Litosseliti L. (ed). Research methods in linguistics. London: Continuum, 2010. 376 p

11. Moldovan D. et al. Models fo the semantic classification of noun phrases. Proceedings of the HLT-NAACL Workshop on computational lexical semantics. CLS '04, 2004. P. 1-9.

12. Mykhaylenko V. V. A glossary of linguistics and translation studies. Ivano-Frankivsk: UPKDG, 2015. 554 p.

13. Mykhaylenko V. V. Conceptual analysis : componential analysis. Science Annals. ChNU Germanic Philology. No120. 2014. P. 77-86.

14. Quirk R. et al. A comprehensive of the English language. London: Longman. 1985. 1792 p.

15. Scott G.J. Stacked adjectival modification and the structure of nominal phrases / Ed. G. Cinque. Functional structure in DP and IP. N.Y.: OUP, 2002. P. 91-120.

16. Semmelmeyer M., Bolander D.O. The New Webster's grammar guide. Berkley Publishing Group, 1992. 286 p.

17. Sproat R., Shih C. Prenominal adjective ordering in English and Mandarin. Proceedings of NELS. 1988. 18 (2). P. 465-489.

18. Warren B. Classifying adjectives. Götenborg, Sweden: Humanities Pr, 1985. 318 p. 